\title{
"SECTAS SATÁNICAS" EN EL MERCOSUR: UN ESTUDIO DE LA CONSTRUCCIÓN DE LA DESVIACIÓN RELIGIOSA EN LOS MEDIOS DE COMUNICACIÓN DE ARGENIINA Y BRASIL
}

\author{
Alejandro Frigerio \\ Universidad Católica Argentina - Argentina \\ Ari Pedro Oro \\ Universidade Federal do Rio Grande do Sul - Brasil
}

Resumen: El asesinato ritual de un niño por un pai-de-santo en el estado de Paraná (Brasil) en 1992 tuvo amplia repercusión en los medios de comunicación de Brasil y Argentina. Cuando también se involucró en el hecho a un grupo platillista (ufo cult) liderado por una brasilera y un argentino, la nacionalidad de los líderes provocó distintas distribuciones de culpabilidad en la prensa de ambos países. La jerarquía de credibilidad de los profesionales propia de cada sociedad determinó la prevalencia de un tipo u outro de "autoridad" opinando sobre el tema en los medios y resultó en el predominio de diferentes interpretaciones sobre el hecho en los dos países -principalmente sobre su carácter excepcional o habitual-así como sobre la peligrosidad de las religiones afrobrasileñas. Desde la perspectiva del etiquetamiento (labeling theory), el trabajo analiza las similitudes y diferencias en la construcción de la desviación religiosa en Argentina y en Brasil y examina en qué medida ésta resultó influida por las mutuas imágenes y prejuicios que estas sociedades vecinas tienen una de la otra.

Palavras-chave: Mercosul, mídia, religiões afro-brasileiras, seitas.

Abstract: The ritual murder of an infant by a purported priest of an Afro-Brazilian religion in southern Brazil in 1992 was widely covered by the media of that country and of Argentina, and created moral panics in both societies. When the leaders of a UFO group (a Brazilian woman and her Argentine husband) were also involved in the affair by the police, their combined nationalities provoked different guilt attributions in the news media of both societies. The hierarchies of credibility characteristic of each country determined the presence of distinct "experts" providing explanations for the events in the Argentine and Brazilian media, and led to divergent evaluations about the recurrence of ritual murders, of "satanic sects " and of the dangerous social consequences of the 
presence of "sects " in these societies. The analysis of this case study through the lens of labeling theory, social constructionism and media studies reveals commonalities and differences in the social construction of religious deviance in Brazil and in Argentina.

Keywords: Afro-Brazilian religion, Mercosul, media, sects.

El asesinato ritual de un niño de seis años por un pai de santo en el estado de Paraná (Brasil) en 1992 tuvo amplia repercusión en los medios de comunicación de Brasil y Argentina. Cuando también se involucró en el hecho a un grupo platillista (ufo religious movement -ver Lewis, 1995) liderado por una brasilera y un argentino, la nacionalidad de los líderes provocó distintas distribuciones de culpabilidad en la prensa de ambos países. La jerarquía de credibilidad de los profesionales propia de cada sociedad determinó la prevalencia de un tipo u otro de "autoridad" opinando sobre el tema en los medios y resultó en el predominio de diferentes intepretaciones sobre el hecho en los dos países -principalmente sobre su carácter excepcional o habitual- así como sobre la peligrosidad de las religiones afrobrasileñas. Desde la perspectiva del etiquetamiento (labeling theory), el trabajo analiza las similitudes y diferencias en la construcción de la desviación religiosa en Argentina y en Brasil y examina en qué medida ésta resultó influida por las mutuas imágenes y prejuicios que estas sociedades vecinas tienen una de la otra.

Para ver en qué medida un suceso aislado es tomado como representativo de las actividades de un determinado grupo religioso o de tipos de grupos religiosos -y cómo en dos sociedades este fenómeno es construido de manera distinta- a continuación desarrollaremos los siguientes puntos: 1) explicitaremos la perspectiva teórica desde la cual analizaremos el fenómeno, 2) brindaremos una breve reseña de cómo se desarrolló la cobertura de los sucesos en diarios argentinos y brasileños, 3) examinaremos cómo fueron encuadrados los hechos dentro de determinados marcos interpretativos que llevaron a una tematización diferente del acontecimiento en Brasil y Argentina y veremos qué rol cumplieron ciertos actores sociales en este proceso, 4) señalaremos qué revela este episodio acerca de las relaciones argentino-brasileras y 5) intentaremos avanzar en la comprensión de la construcción de la desviación religiosa en ambos países. ${ }^{1}$

1 La investigación que dio origen a este trabajo fue parcialmente financiada por un subsidio para la cooperación. 


\section{La construcción social de la desviación religiosa: activistas morales, reclamos y arenas institucionales}

Para estudiar la definición colectiva de la desviación, es preciso resaltar el rol de los moral entrepreneurs (activistas morales) (Becker, 1963) o reclamadores (Best, 1990) que presentan ciertas condiciones sociales como problemas o ciertos comportamientos como desviantes y proveen un marco interpretativo (frame) para comprenderlos. Es preciso tener en cuenta, además que en cada sociedad, en un momento dado, existe una determinada jerarquía de credibilidad (Becker, 1967) por la cual ciertos grupos tienen un mayor poder que otros para definir y legitimar una determinada interpretación de la realidad -o ciertas acusaciones o etiquetas de desviación (deviance designations) (Conrad; Schneider, 1992, p. 27). En las sociedades modernas el lugar en esta jerarquía frecuentemente está asociado a la posesión de conocimiento científico -o que se pueda hacer pasar por científico (Frigerio, 1993). El objetivo último de los reclamadores es llegar a constituirse en los dueños del problema, actuando como guardianes que controlan la definición pública del problema o del comportamiento desviante y logran algún grado de control sobre las políticas sociales que se tomen respecto del mismo (Gusfield, 1981).

La perspectiva constructivista de los problemas sociales (Best, 1990; Frigerio, 1997; Hilgartner; Bosk, 1988; Schneider, 1985; Spector; Kitsuse, 1987), además de resaltar el rol de los reclamadores, enfatiza también la importancia de diversas arenas institucionales en las cuales se desarrolla la competencia por la definición de una condición como problema o de un comportamiento como desviante: los medios de comunicación masivos, debates en el congreso, oficinas del poder ejecutivo, los tribunales, las sociedades profesionales o las organizaciones religiosas (Hilgartner; Bosk, 1988). Hay patrones de interacción entre las diversas arenas que hacen que las actividades desarrolladas en una de ellas se expanda a las demás.

\section{El rol de los medios de comunicación}

Los medios de comunicación son la arena institucional más importante para la construcción de problemas o para el etiquetamiento de comportamientos como desviantes, ya que construyen y mantienen la realidad pública de 
una sociedad, "lo que todos saben" acerca de determinados temas o de lo que está sucediendo en el país.

De la enorme cantidad de eventos que se producen cada día en una sociedad, los medios seleccionan -según criterios internos derivados de sus propias rutinas de producción- cuáles serían lo suficientemente importantes para ser considerados como noticias. Es por esto que se suele afirmar que los medios construyen las noticias (Alsina, 1989; Van Dijk, 1990). Las noticias, a su vez, son frecuentemente agrupadas y tratadas como parte de un tema mayor (Wolf, 1991, p. 185-185). ${ }^{2}$ Ciertos temas pueden adquirir una dimensión desproporcionada en los medios y otros -que de acuerdo con los criterios de otros actores sociales podrían ser relevantes- son omitidos.

El acceso a los medios es especialmente importante para los reclamadores que son outsiders, es decir que pertenecen a grupos tradicionales de presión y no tienen acceso por sí mismos a legisladores o funcionarios (Best, 1990). Presentando su marco interpretativo de un determinado problema en los medios, tratan de lograr el apoyo del público que les permita luego influir en otros ámbitos (especialmente sobre los gubernamentales, para lograr acciones que favorezcan o apoyen su interpretación del problema). Los medios, además, por su constante necesidad de temáticas novedosas y dramáticas que puedan ser transformadas en noticias, son más receptivos que los legisladores o funcionarios a los reclamos realizados por outsiders.

Nuestra dependencia de los medios para el conocimiento de ciertos hechos y sobre todo para su interpretación es mayor cuanto menos experiencia directa tenemos sobre un determinado tema. En la medida en que aquellos con quienes usualmente conversamos y reinterpretamos los mensajes de los medios -nuestra pareja, compañeros o familiares- también dependen de ellos para su conocimiento de ese tema determinado, dificilmente podamos llegar a una opinión muy diferente de aquella que nos es presentada (Gamson, 1988; Gamson et al., 1992).

Por este motivo, para el caso de los nuevos movimientos religiosos, estigmatizados como "sectas", la imagen que se transmite a través de los medios

\footnotetext{
2 Según Wolf (1991, p. 184), el concepto tematización indica "la transformación y el tratamiento de un cierto número de acontecimientos y hechos distintos en un único ámbito de importancia”. Lo que distingue a un tema de un acontecimiento es "no sólo el recoger una serie de acontecimientos a lo largo del tiempo [...] sino el hacer converger esta misma serie de acontecimientos en la indicación de un problema que tenga significado público y que reclame una solución” (Wolf, 1991, p. 185).
} 
de comunicación resulta particularmente relevante, ya que la mayor parte de los individuos no han tenido un contacto directo con estos grupos y dependen casi exclusivamente de la información transmitida por los medios para opinar sobre ellos (Bromley; Shupe; Busching, 1981; Frigerio, 1993; Van Driel; Richardson, 1988).

\section{Reclamos y marcos interpretativos}

Según el análisis de Best (1990, p. 19), si los operadores presentan sus reclamos primarios a los medios (mediante demostraciones públicas, conferencias de prensa, o gacetillas), éstos "tienen sus propias preocupaciones y convenciones que moldean cualquier mensaje que transmitan. Los medios no sólo transmiten mensajes, los traducen y transforman antes de que lleguen a su audiencia. La cobertura de los problemas por los medios puede ser, entonces, concebida como un reclamo secundario". Estos reclamos no sólo se transmiten a través de los noticieros, sino también a través de programas periodísticos, de interés general y aún programas de ficción, o de humor, todos éstos sub-ámbitos de creciente importancia en el mercado de problemas sociales (Frigerio, 1998; Gamson; Stuart, 1992).

Entonces, si los reclamadores intentan imponer ciertos frames o marcos interpretativos que den cuenta de la realidad social, los periodistas a su vez tienen sus propios frames mediante los cuales seleccionan ciertos hechos como acontecimientos, enfatizan ciertos aspectos de éstos y los presentan como noticias (Tuchman, 1978, p. 7, 193). Sus marcos serían teorías tácitas (más o menos desarrolladas) sobre qué existe, qué sucede y qué es lo relevante (Gitlin, 1980, p. 6). Aunque "mayormente no mencionados ni reconocidos, los marcos de los medios organizan el mundo tanto para los periodistas que lo reportan como -de una manera importante- para quienes dependemos de sus notas” (Gitlin, 1980, p. 7).

La más rápida aceptación de un reclamo o de una interpretación de un problema social se ven también afectados por la prevalencia de ciertos temas culturales presentes en cada sociedad (Gamson, 1988a, 1988b, 1992; Gusfield, 1981; Hilgartner; Bosk, 1988).

Gamson y Modigliani (1989, p. 5) afirman que "no todos los símbolos son igualmente potentes. Ciertas interpretaciones tienen una ventaja natural porque sus ideas y lenguaje resuenan con temas culturales más englobantes. 
Las resonancias aumentan la aceptación de una interpretación, la hacen parecer natural y familiar. Quienes responden al tema cultural mayor podrán aceptar más fácilmente una interpretación con su misma sonoridad”. Gamson (1988a) define a los temas culturales como "marcos interpretativos y símbolos relacionados a éstos que trascienden temas específicos y sugieren cosmovisiones mayores. Es un concepto parecido a palabras como ideología, valores, sistemas de creencias y Weltanschauung. Prefiero utilizar un concepto que haga las menores presunciones posibles acerca de la coherencia o de las conexiones entre las ideas". ${ }^{3}$

\section{Problemas sociales y pánicos morales}

En ciertos momentos particulares de ebullición social, la lucha por imponer un marco interpretativo se hace particularmente virulenta y en ocasiones uno de estos marcos gana una aceptación inusitada en varios ámbitos sociales. Cuando ciertos reclamadores logran convencer a sectores importantes o influyentes de la sociedad acerca de la evidente peligrosidad que reviste un problema social o un comportamiento desviante, y por lo tanto también de la urgente necesidad de su control, es muy probable que estemos ante un pánico moral. Siguiendo el pionero análisis de Cohen (1972), y también trabajando desde una perspectiva constructivista, Goode y Ben-Yehuda (1994) han propuesto este concepto de suma utilidad para analizar fenómenos sociales de inusitada dinámica e intensidad en la construcción de un problema social o el etiquetamiento de la desviación social. Los pánicos morales se producen cuando "un número importante de los miembros de una sociedad se preocupan intensamente por algún tipo de amenaza cuyas evidencias, cuando analizadas objetivamente, son casi inexistentes o considerablemente menores de lo que se creeen” (Goode; Ben-Yehuda, 1994, p. 149). Durante un pánico moral se crean "demonios populares” o figuras demonizadas (folk devils):

\footnotetext{
Aunque Gamson es quien más ha enfatizado la importancia de los temas culturales, otros autores han realizado afirmaciones similares. Hilgartner y Bosk señalan que en todos los ámbitos públicos en los cuales se construye la desviación social operan determinados principios de selección que influyen sobre la probabilidad de que algunos temas sean conceptualizados de la forma en que los activistas morales lo proponen. Según estos autores, "los problemas sociales que pueden ser relacionados con temas míticos o preocupaciones culturales específicas de la sociedad tienen una mayor probabilidad de competir exitosamente” (que otros problemas que no puedan establecer esa relación) (Hilgartner; Bosk, 1988, p. 71).
} 
estereotipos desviantes que identifican al enemigo y se crean o se reclaman medidas especiales para su control. ${ }^{4}$

Cuando los pánicos morales se restrigen a una determinada localidad geográfica es muy probable que su desarrollo pueda ser explicado como efecto de rumores que circulan por el área. Cuando trascienden el nivel local y adquieren una dimensión más nacional, es muy probable que -debido a la influencia de los medios de comunicacion en la construcción de la realidad pública- sea a través de los reclamos (secundarios) realizados por los medios de comunicación masiva que dicho marco interpretativo adquiera una relevancia pública inusitada (Goode; Ben-Yehuda, 1994; Victor, 1993). ${ }^{5}$

Tomando los conceptos desarrollados dentro de estas perspectivas constructivistas, analizaremos la desigual repercusión que el asesinato -supuestamente ritual- de un niño tuvo en dos países. Para ello, a continuación describiremos la secuencia de noticias aparecidas en diarios y revistas de Brasil y Argentina que dieron cuenta del asesinato y lo relacionaron con otros hechos, así como las reflexiones que sobre el evento fueron publicadas. Para el caso brasilero, utilizaremos principalmente el diario Folha de São Paulo y las revistas Veja e Istoé, y para el caso argentino los diarios Clarín, La Nación y Página 12, así como las revistas semanales Noticias, Somos y Gente. ${ }^{6}$

\footnotetext{
4 Según Goode y Ben-Yehuda (1994, p. 156-158), existen por lo menos cinco elementos que caracterizan a los pánicos morales: 1) preocupación: debe haber un elevado grado de preocupación acerca del comportamiento (real o supuesto) de un cierto grupo o categoría social y de sus consecuencias para el resto de la sociedad. Esta preocupación se manifiesta de maneras concretas: encuestas de opinión, atención de los medios, proyectos de leyes o actividades de grupos o movimientos sociales; 2) hostilidad: debe haber un mayor nivel de hostilidad hacia la categoría de personas que se cree participan del comportamiento amenazante. A éstos se los considera enemigos de la sociedad respetable y cumplidora de la ley. Se produce una dicotomización entre "ellos" y "nosotros", y esto incluye la creación de estereotipos, villanos (folk-devils) por un lado y héroes populares por el otro; 3) consenso: debe haber un mínimo de consenso en la sociedad o en segmentos importantes de esta -no necesariamente en la mayoría- de que la amenaza es real y seria. Hay pánicos morales de distintos tamaños: algunos abarcan a ciertos segmentos o categorías sociales, otros preocupan ala mayor parte de la sociedad; 4) desproporcionalidad: en el concepto de pánico moral está implícita la idea de que la preocupación es desproporcionada con la naturaleza de la amenaza. Durante los pánicos morales la producción y circulación de cifras exageradas de víctimas de la amenaza -muertos, adictos, heridos, enfermos- es común; 5) volatilidad: los pánicos morales son volátiles. Surgen de repente, y pueden desaparecer rápidamente. Aunque pueden tener algún impacto a largo plazo, el grado de miedo, hostilidad y preocupación generado durante un pánico moral tiende a ser limitado temporalmente.

5 Victor (1993) muestra cómo durante los pánicos morales se da una interacción entre rumores locales y la cobertura nacional de un determinado problema.

6 Tomaremos en cuenta las noticias aparecidas durante el período en que el hecho se convirtió en un acontecimiento periodístico -entre julio y octubre de 1992.
} 


\section{Desarrollo de las noticias en Brasil y Argentina}

\section{a) En Brasil}

En Brasil, el hecho fue cubierto por todos los medios de comunicación. La Folha de São Paulo fue, probablemente, el medio nacional que más lo cubrió, con notas casi diarias durante todo julio (en sólo 6 días no lo trató). Entre las revistas, Veja e Istoé le dedicaron notas de varias páginas. Si el caso no recibió una atención aún mayor por parte de la prensa fue porque en la época (julio de 1992), ésta -al igual que todo el país- estaba pendiente de las actividades de la Comisión Parlamentaria de Investigación que investigaba las irregularidades atribuidas al presidente Femando Collor, que culminaron con su empeachment. El desarrollo de las noticias refermas al caso en la Folha de São Paulo fue el siguiente:

\section{3/7: Acusados de matar un niño en un ritual satánico son detenidos} en Paraná

La policía militar de Paraná detiene a 5 personas acusadas de haber participado en la muerte de Evandro, un niño de 6 años, en un ritual de magia negra realizado en Guaratuba 3 meses antes. Los acusados son Marceneiro, jefe de una casa de umbanda en Guaratuba y quien según la prensa es llamado "brujo" en esa ciudad; dos de sus ayudantes, y la mujer y la hija del intendente de Guaratuba, quienes habrían ordenado la muerte del niño.?

\section{4 - 12/7: Investigan si el intendente está involucrado en el caso y si existe ligazón con la desaparición de otro niño en Curitiba}

En sus declaraciones a la Folha, el secretario de Seguridad Pública de Paraná manifestó que Evandro "fue secuestrado y luego asesinado en un ritual de magia negra en el que se le pedía a Exu (figura asociada al diablo en

\footnotetext{
A fines de abril de 1998, Celina Cordeiro y Beatriz Abage -esposa e hija del ex-intendente de Guaratubafueron declaradas inocentes por un tribunal de São José dos Pinhais, localidad próxima a Curitiba. Según la Folha de São Paulo (28/04/1998), "o conselho de sentença disse que Celina e Beatriz foram absolvidas porque não foram reunidos documentos suficientes para provar que o corpo encontrado em um matagal era o de Evandro". El juicio de ambas mujeres duró 34 días y fue el más prolongado de la historia de la justicia brasilera. Otros acusados (Marcineiro y dos de sus auxiliares, así como dos ex-funcionarios de la Intendencia de (Guaratuba) deberán ser juzgados en el segundo semestre de este año (1998).
} 
el Candomblé) protección y éxito financiero” (para el intendente). La policía presentó una grabación en la cual la mujer y la hija del intendente confiesan que encargaron el asesinato de Evandro. Se cree que Marcineiro también podría ser responsable por la desaparición de Leandro, un niño de 9 años que desapareció en Curitiba en febrero -fecha que coincide con su estadía en dicha ciudad.

\section{3-14/7: Un grupo de argentinos estaría ligado al ritual satánico}

El día 13, Marcineiro confiesa que, pagado por la mujer del intendente, secuestró al otro niño, Leandro, para que "fuera enviado a una secta fuera del Brasil “probablemente de argentinos” para ser sacrificado". Ya en una llamada en tapa del día 14 -en la que resume el contenido del caderno Cotidiano- la Folha afirma “Argentinos podem estar ligados a ritual satánico”.

\section{4/7 - 1/8: Caza a los brujos / "A trilha da magia negra”}

La supuesta participación del grupo argentino le da un giro a la presentación de la información. Los artículos ahora enfatizan los esfuerzos de la policía por encontrar al "brujo" argentino José Teruggi y a su mujer, la "bruja” brasilera Valentina de Andrade. Detallan sus posibles implicaciones en los crímenes y describen la información que se va obteniendo respecto de la organización y creencias del grupo. El 24/7 el diario destaca (en primera página) que se encontró un video donde Teruggi, en trance, pide a su mujer que "matem muitas criancinhas", porque "é a riqueza energética".

A la vez que relatan los esfuerzos por atrapar al brujo argentino y la bruja brasilera, van apareciendo noticias de otros hechos que podrían estar conectados con los de Guaratuba: cinco niños muertos en São Luiz entre septiembre del 91 y marzo del 92; una niña violada y asesinada en Goiânia; restos óseos encontrados en Rio Claro (SP), un cráneo humano encontrado en Viamão (RS), la venta de cadáveres de niños en cementerios de São Paulo. Según los periodistas, estos hechos se conectarían causalmente entre sí -piensan que Marcineiro o Taruggi podrían estar involucrados- o mostrarían la ubicuidad de actividades de magia negra en el país.

\section{2/8: Reflexiones sobre el esoterismo en Brasil}

Con el título de "As bruxas estão soltas: crimes causados por rituais satânicos colocam em discussão a crescente onda de misticismo no Brasil”, la 
Folha de São Paulo dedica varias páginas de su "caderno Mais” para reflexionar sobre un supuesto auge de prácticas esotéricas en el país y su posible relación con el asesinato del niño.

\section{5-7/8: Tumultos en Guaratuba}

En agosto, la cobertura del caso disminuye notablemente. Tan sólo en siete ocasiones la Folha se refiere al tema, y exceptuando la serie de notas del día 2, las otras seis se focalizan mayormente en los sucesos locales. El intendente de Guaratuba, cuya esposa e hija están acusadas de participar en el asesinato, reasume su cargo pero luego de tres días de manifestaciones en su contra es cesanteado por los vereadores -quienes lo acusan de abuso de poder (por una causa no relacionada con el caso Evandro).

\section{1/8 - 25/9: Idas y venidas en la causa judicial}

Durante el mes de septiembre aparecen seis notas, referidas en su mayoría al desarrollo de la causa. Hablan de las escasas pruebas aportadas, de los testigos, y sobre todo, de una serie de incidentes con ella relacionados: dos individuos intentan robar las actas; se realiza una marcha de 80 personas acusando a la policía civil de proteger a los acusados; y la propia jueza pide la remoción del delegado de esta fuerza. Revocan la prisión preventiva dictada contra Valentina.

\section{6/9 - 26/10: Desvinculan a Valentina y Teruggi del asesinato de me- nores pero los acusan de estafa}

La cobertura durante octubre es realmente esporádica; sólo aparecen cuatro notas, casi todas referidas a la situación procesal de Valentina y Teruggi. El 26 de septiembre son detenidos y liberados por la policía federal brasilera. El 7 de octubre una pericia muestra que la frase del video incriminador era "mas tem criancinhas" y no "matem as criancinhas". Ahora es sólo la policía civil de Londrina que los acusa por estafar a sus seguidores.

\section{b) en Argentina}

En Argentina, la noticia fue cubierta durante un mes, con notas cada día en todos los diarios de Buenos Aires y con notas semanales en todas las revistas de política y actualidad. Recibió, asimismo, profusa cobertura en 
programas de televisión, tanto noticieros como de interés general. El diario Clarín, que combina una tirada masiva de ejemplares con credibilidad periodística, mandó un enviado especial a Guaratuba del 24 de julio al 5 de agosto, razón por la cual durante más de una semana tuvo notas de casi dos páginas dedicadas al hecho. En cuatro oportunidades, este diario sacó el tema en primera página (“Secta Satánica: Maten al niño que pedí” (24/7); “Cómo operaba la secta satánica que sacrificaba niños” (26/7); "Investigan a la secta satánica en Argentina” (28/7); "Detuvieron y liberaron a Valentina y Teruggi en Concordia” (25/9). En otros diarios prestigiosos, la cobertura también fue diaria pero las notas fueron menores y hubo menos llamadas al tema en la portada.

En la prensa argentina, el desarrollo del tema se dio de la siguiente manera:

\section{1-14/7: Un niño es sacrificado ritualmente en Brasil}

Notas pequeñas, aisladas, dan cuenta del asesinato, presuntamente ritual realizado por un "brujo" (Marcineiro) en Brasil.

\section{5/7: Habría argentinos involucrados en el asesinato}

Según informaciones dadas por la policía brasilera, habría "un grupo de argentinos” involucrado en el hecho. Se menciona el nombre del líder, José Teruggi. Aquí comienzan las coberturas diarias del tema.

\section{6 - 26/ 7: La “secta” LUS está involucrada}

Ampliando los datos de la policía brasileña -que ya habían identificado a José Teruggi y Valentina de Andrade- dos “especialistas en sectas” argentinos brindan una conferencia de prensa en la que detallan aspectos de su sistema de creencias. Ella es la ideóloga del grupo, que cree en los contactos con extraterrestres y que los niños nacidos después de 1981 poseen una energía nefasta. La policía brasilera dice que Marcineiro le entregó un niño a la secta argentina para que lo sacrifiquen, mientras que los especialistas argentinos creen que, debido a su creencia de que los niños son nefastos, Valentina y marido podría haber secuestrado a cambio de dinero para que los sacrifiquen en Brasil. Hasta el 26/7, el foco de atención son los acontecimientos en Brasil, principalmente se tejen toda una serie de conjeturas acerca del papel que jugó la "secta satánica” de Teraggi y Valentina en los secuestros y sacrificios. 
27/7: Allanan un templo de Umbanda en Buenos Aires donde se realzan sacrificios de animales. Se acusa al pai de corrupción de menores

Esta noticia sale, desde el primer día, en todos los diarios en las mismas notas en que se habla de LUS.

\section{8 - 30/7: Un sacerdote católico denuncia que un pai realizó un cri- men ritual en Buenos Aires}

Según un sacerdote católico, "Lo de Brasil no es nuevo, y mucho menos en Argentina, donde ya hay antecedentes de sacrificios humanos en rituales de magia negra”. Acusa a un pai y a dos ayudantes de matar y descuartizar a una niña de 13 años. Aunque esta noticia sólo es reportada dos días en los diarios (aparece también en recuadros en las notas de revistas semanales), tiene gran repercusión en la televisión, donde se la trata en noticieros, programas periodísticos y de interés general.

2-3/8: Reflexiones sobre las sectas como problema social en el país

Aparecen artículos de dos y tres páginas en los diarios que describen el problema de las sectas, dicen cuantas hay en Argentina, como funcionan y cuáles son sus peligros, A esta altura de la controversia, el tema merece también el comentario editorial de los dos diarios más prestigiosos de la ciudad (“Ceremonias Satánicas”, La Nación 3/8 y "Supersticiones peligrosas”, Clarín 3/8).

\section{4 - 16/ 8: La Iglesia y el Estado muestran preocupación por las sectas} / Siguen los procesos contra LUS y pai Umbandista

Durante la primer quincena de agosto, los diarios siguen dando noticias de los desarrollos en el caso LUS, así como de la prohibición de funcionar de la "secta” Filhos de Oxalá (el pai cuyo terreiro fue allanado el 27/7, y cuyo inscripción en el Registro Nacional de Cultos fue cancelada).

A la vez, aparecen noticias sobre la aparente preocupación de importantes actores sociales con "el problema de las sectas”: el Estado y la Iglesia Católica. Dos notas dan cuenta de que se acelerará la presentación al Congreso de una nueva Ley de Cultos y de reformas al Código Penal vinculadas a temas religiosos ("Enviarán al Congreso proyectos para vigilar el comportamiento de las sectas” Clarín 4/8 y "Un colador para las sectas”, Página 12 4/8 ). Mediante las primeras, se restringirá la inscripción de grupos religiosos en el Registro Nacional de Cultos; mediante las segundas se penará la “captación 
de conciencia”. Por otro lado, la presentación ante la Conferencia Episcopal Argentina de un informe sobre la presencia de nuevos movimientos religiosos en el país es tomado como prueba de la preocupación de la Iglesia por las “sectas” (“Obispos y Sectas” -La Nación 11/8; "La Iglesia pide cambios en el Registro de Cultos”-Clarín 13/8; “Conferencia episcopal: Sectas, por mi grandísima culpa”-Página 12, 14/8). ${ }^{8}$

\section{5-26/9: Aparecen Valentina y Teruggi}

A mediados de agosto (luego de 30 días de notas casi diarias) las noticias sobre el evento prácticamente desaparecen. Recién a fines de septiembre los medios tratan nuevamente el caso, para reportar -durante dos días, en el primero con títulos en primera página- la detención por unas horas de Valentina y Teruggi por la policía argentina cerca de la frontera con Brasil, en viaje a Parana para declarar ante la jueza brasileña.

Esta descripción de las noticias y eventos que, a partir de la muerte supuestamente ritual de un niño, fueron sucesivamente vinculadas entre sí muestra la divergente tematización que, en ambos países, se realizó de los hechos. Esta diferente tematización llevó a que -como examinaremos a continuación con mayor detalle- en Argentina y Brasil hubiera preocupación por problemas sociales distintos: En Argentina, por el problema de las sectas, en Brasil, por el de la magia negra. Para entender cómo se dio este proceso, es necesario ver cómo fue enmarcado (framed) el hecho en los medios, y quiénes fueron los expertos que opinaron acerca del mismo en ambos países.

\section{Marcos interpretativos y reclamodores}

En Brasil, los medios tematizaron a los hechos bajo el rótulo "crimen satánico” o “ritual satánico”. Este era el título que, día tras día, señalaba claramente que era una misma historia la que se estaba desarrollando. Esta historia incluía como protagonistas a Marceneiro y sus secuaces culpados de asesinar a Evandro; a la mujer y la hija del intendente de Guaratuba, que

8 En la medida en que éste informe fue encargado y realizado antes de los sucesos de Guaratuba, y que los obispos nunca se pronunciaron sobre éstos, la relación que establecieron los medios entre la reciente preocupación social por las sectas y la reunión de los obispos constituye una elaboración de reclamos secundarios por parte de los periodistas. 
supuestamente los habrían incitado a cometer el macabro crimen y a Teraggi y Valentina, sospechosos de haber secuestrado o sacrificado a otro niño. Tenía, además, como telón de fondo otras actividades sospechadas de ser "satánicas" -más homicidios, utilización y venta de huesos humanos.

En Argentina, por el contrario, los diarios se refirieron al caso más frecuentemente como el de la "secta satánica". ${ }^{9}$ La diferencia es significativa, ya que la palabra "secta” remite -según la interpretación que veremos se transformó en hegemónica- a grupos organizados para una determinada actividad y además permite establecer una relación con otros grupos considerados "sectas” que aunque no sean "satánicas”, por el hecho de ser sectas tienen algo en común con esta "secta satánica”.

Para entender cómo, en este último país, se realizó una determinada tematización de los hechos, y cómo su comprensión bajo un cierto marco interpretativo llegó a ser hegemónica -el que sostenía que éste era un caso de "sectas"- debemos analizar quiénes fueron los expertos que mayormente interpretaron estos eventos en los medios (varios de ellos reclamadores, según la terminología que propusimos al principio del trabajo). Asimismo, cuáles fueron los reclamos secundarios (Best, 1991) que los periodistas realizaron en base a los originales.

\section{En Argentina}

Analizando los expertos que fueron llamados a opinar sobre los hechos, vemos una importante diferencia entre ambos países. En Argentina, aparecen repetidamente en los diarios y revistas las opiniones de tres "especialistas en sectas", individuos que lideran o pertenecen a agrupaciones que tienen como objetivo "el estudio de las sectas". Dichas agrupaciones podrían ser ubicados dentro de lo que en los estudios americanos se conocen como anticult movement organizations (Bromley) y que en estudios anteriores Frigerio (1993) ha descripto como “organizaciones anti-sectas”. En la controversia

\footnotetext{
9 Cuando, a fines de julio se acusó a un pai umbandista local de sacrificar animales y de corromper menores, y a otro de realizar un sacrificio humano en sus rituales, varios periodistas -principalmente en la televisión-empezaron a hablar de "sectas “ (satánicas o diabólicas). Varios locutores en noticieros, por ejemplo, se refirieron a los eventos de la siguiente manera: "un tema estremecedor, las sectas que sacrifican niños” (Telenoche, 27/ 7); "increíble., sectas masacradoras de niños” (Nuevediario, 28/7); “en nuestro país, se conocen nuevas víctimas de las sectas que rinden culto al demonio” (Telenoche, 28/7).
} 
desatada alrededor del grupo LUS, los activistas anti-sectas jugaron un papel especialmente importante porque no sólo ofrecieron interpretaciones acerca del fenómeno general de las sectas, sino que también -y esto quizás les permitió luego hegemonizar la interpretación del fenómeno, convirtiéndose en los dueños del problema (Gusfield, 1981)- fueron fundamentales fuentes de la información periodística, de esta manera contribuyendo a co-crear el acontecimiento periodístico (ver Frigerio, 1993).

Dos de estos activistas (los periodistas Alfredo Silleta, presidente de la Fundación Argentina para Estudio de las Sectas y Alejandro Agostinelli, directivo del Centro Argentino para la Refutación e Investigación de la Seudociencia) fueron quienes, a través de una conferencia de prensa efectuada el 15/7 y reproducida por casi todos los medios, revelaron que los "brujos" Teruggi y Valentina eran en realidad los líderes de una secta platillista "destructiva” denominada LUS. Brindaron también la primera información acerca de las creencias del grupo, especialmente su supuesta aversión hacia los niños nacidos después de 1981. El 23 de julio dieron una segunda conferencia de prensa, y presentaron a los medios a Claudio Rodríguez, un ex-miembro y en ese momento crítico del grupo LUS que luego fue reporteado por casi todos los medios. Pocos días después, presentaron una denuncia contra la secta LUS ante la Asesoría de Menores para que ésta a su vez fuera elevada a un Juzgado de Menores, intentando que la justicia tomara medidas cautelares "para evitar la fuga de los líderes sectarios buscados en Brasil”. ${ }^{10}$ La presentación de esta denuncia también fue reportada por los diarios.

Los activistas antisectas no sólo realizaron actividades que los medios cubrieron como una forma de brindar novedades sobre el caso (sus conferencias de prensa y su denuncia) sino que también aportaron datos sobre la secta LUS que, ante la carencia de informaciones sobre el grupo, luego serían reproducidos por todos los diarios argentinos y muchos brasileros. Estos incluían

${ }^{10}$ Entre las actividades figura también una reunión con el cónsul brasilero en Buenos Aires, al cual le dieron toda la información que tenían sobre el grupo, incluida una lista de 300 miembros de LUS. El propio Alejandro Agostinelli relata en un artículo aparecido en la revista del CAIRP El Ojo Escéptico “el papel que jugó el Cairp en esta compleja historia”. En este artículo brinda un completo detalle de sus esfuerzos junto a Alfredo Silleta por llamar la atención de los medios y realiza un interesante balance de las acusaciones que se le realizaban a LUS en Brasil, exponiendo cuales eran sus propias ideas acerca del posible rol de esta "secta destructiva” en el crimen (El Ojo Escéptico \#5, septiembre de 1992, suplemento especial de 12 páginas dedicado al caso Valentina). 
antecedentes históricos del grupo, algunos de sus lincamientos doctrinarios, citas del libro de Valentina y unos pocos testimonios de ex-miembros.

En la primer conferencia de prensa, Silleta y Agostínellí también brindaron su interpretación acerca de cómo el grupo LUS podría estar involucrado en los hechos de Guaratuba. Afirma Silleta: "Lo que queremos es prevenir para que la gente sepa que LUS es una secta destructiva, nacida en la Argentina en 1984 y que congrega adeptos a través de la investigación del tema OVNI, está basada en la negatividad de Dios y considera que los niños nacidos a partir de 1981 son negativos. Por esto es que existe la posibilidad de que este grupo pueda vender o entregar a niños de sus seguidores para obtener algún rédito económico. Esta afirmación se basa en el testimonio de varios ex-adeptos de esa secta" (Crónica 16/7). ${ }^{11}$

Quizás el aporte más significativo de los activistas anti-sectas a la forma que tomó la controversia no fueron sólo los datos que poseían sobre LUS, sino sobre todo el marco interpretativo (frame) que propusieron acerca de qué tipo de fenómeno era éste que llamaba la atención de los medios. Su interpretación brindaba informaciones generales de qué eran las sectas -qué tipo de actividades realizan, cuál es su forma de organización, qué peligros acarreaban para sus integrantes y la sociedad-y de cuáles eran, permitiendo así conectar este hecho con otros episodios en los cuales sucedieron cosas habituales en las sectas.

Por ejemplo, dos diarios reprodujeron declaraciones del sicólogo Baamonde, director de SPES (Servicio para el Esclarecimiento en Sectas) que conectaban claramente al grupo LUS con la actividad arquetípica de las "sectas": el suicidio colectivo. ${ }^{12}$ En una entrevista sugestivamente titulada:

"Dicen que planeaban una matanza como en Guyana", Baamonde afirmó: "Los seguidores de LUS que llegaron a SPES nos contaron que Valentina estaba achicando su grupo porque [...] las mentes superiores harían un rescate en energía [...] rescatarían sólo la energía de los cuerpos de cada uno, no la materia. "Nuestros cuerpos quedarán como muertos" contaban,

11 La información dada en la conferencia fue transcripta de distintas maneras (con mayores o menores citas textuales) en todos los diarios de Buenos Aires. Aquí reproducimos el trecho del diario Crónica porque es el que brinda la cita textual más larga.

12 Varios trabajos muestran cómo el suicidio colectivo de los miembros del Templo del Pueblo en Guyana en 1978 coloreó la imagen que los medios y el público en general tienen de los nuevos movimientos religiosos (Barker, 1986; Frigerio, 1993, 1996a). 
como si estuvieran diciendo algo muy obvio y extremadamente normal. "Esto ocurrió en el 91 y no bien nos dimos cuenta de que lo que estaba pasando podía terminar como la masacre de Guyana salimos a denunciarlo en cuanto lugar pudimos" (Clarín 21/7).

La influencia progresiva del marco interpretativo propuesto por los activistas anti-sectas se puede apreciar en la manera en que cambió la rotulación del caso. Los titulares de las primeras notas argentinas sobre el caso mencionaban "ritos satánicos” o “crímenes satánicos” -haciendo eco de la información que llegaba de los medios y la policía brasilera. Luego de la sostenida intervención de los “especialistas en sectas" en los medios (a partir de su primera conferencia de prensa y durante casi una semana Silleta, Agostinelli, Baamonde y el apóstata Rodríguez fueron prácticamente las únicas fuentes citadas en los diarios) el hecho fue tipificado en los titulares como "Secta satánica” y Teruggi y Valentina pasaron de "brujos” o "líderes esotéricos” a ser considerados "los lideres de la secta".

Los otros hechos con los cuales los medios locales establecieron conexiones (a diferencia de lo ocurrido en Brasil) también muestran que el evento se enmarcó como "actividades de sectas". Estos hechos habitualmente aparecieron como recuadros dentro de las notas que trataban sobre el caso LUS. Algunos ejemplos:

El primer recuadro que ligó los crímenes en Brasil con otros hechos fue uno que rememoró las matanzas producidas a raíz de un exorcismo dentro de un grupo de indígenas mapuches pertenecientes a una "secta" pentecostal, así como los crímenes de Charles Manson ("Matanzas rituales: del caso Manson al de los mapuches" -Clarín 17/7). El segundo fue la ya descripta entrevista a Baamonde en la que el especialista relataba su temor de que intentaran un suicidio ("Dicen que planeaban una matanza como en Guyana" -Clarín 21/7). Además de las matanzas (de propios o ajenos) los artículos pasan a enfatizar el hecho de que en las sectas también se separa a las personas de sus familias, llegando al extremo de que puedan desaparecer dentro de éstas. Esto se aprecia claramente en el título en la portada de la primer revista que encuadró las actividades de LUS dentro del tema más amplio de las sectas -que incluía un reportaje de una página a Silleta. Esta leía: "Ritos satánicos: Cuidado con las sectas que apartan de los amigos y la familia y terminan enloqueciendo a los adeptos (aunque no se den cuenta)! " (revista Esto! 23/7). 
Otros dos recuadros aparecidos en el diario Clarín fueron particularmente reveladores de que este marco interpretativo iba ganando fuerza. El primero relató el caso de una madre e hija que desaparecieron del hogar a comienzos de año: "Hoy (el marido) desempolvó una vaga sospecha. Hace algunos años, en Entre Rios, patria chica de su mujer, ella había manifestado interés en una secta afroamericana [...]" ("El misterioso caso de una madre y su hija desaparecidas"-Clarín 24/7).

Un caso similar apareció al día siguiente: "Á partir de la proliferación de las sectas, se han convertido en moneda corriente las denuncias policiales sobre la desaparición voluntaria de muchísimas personas. " (Una mujer, cuyo hermano y nuera desaparecieron) "recordó que una vez alguien los acercó a un nuevo movimiento de corte religioso [...] Comenzaron a ir cada vez mas seguido. Al mismo tiempo, fueron abandonando sus cosas de todos los dias, empezaron a tener conflictos con el resto de la familia. Hace dos años desaparecieron como por arte de magia". [...] En su casa encontraron "pilas de volantes que prometían una nueva vida, mucho mejor y el rechazo total a los viejos valores “. El recuadro está ilustrado con una foto del matrimonio desaparecido, y abajo el epigrafe "Un familiar denunció su desaparición: “Están en una secta “aseguró” (“Otra misteriosa desaparición”-Clarín 25/ 7, nuestro énfasis).

La primera línea de la nota muestra los esfuerzos del periodista por encontrar la relevancia para el artículo sobre Valentina de un caso ocurrido dos años atrás; al mismo tiempo, la inclusión de este caso inconsistente y antiguo sólo se justifica dentro del marco interpretativo que se estaba imponiendo: el de que las sectas son lugares siniestros donde la gente desaparece o la matan.

El marco interpretativo de las "sectas permite realizar asociaciones entre eventos o actores cuya interrelación nunca estuvo clara. Un periodista de una popular revista argentina afirma: “[...] el poder municipal, un grupo Umbanda (Marceneiro) y dos esotéricos turistas argentinos (LUS) se conectaban en un solo punto: SECTA.” (“Satánicos”, revista Gente 23/7, énfasis en el original).

Los "crímenes rituales" quedaron defintivamente englobados como parte de un problema social mayor, "el problema de las sectas" cuando, a diez días de comenzado el escándalo sobre el asesinato en Brasil, un templo de Umbanda porteño fue allanado por realizar sacrificios de animales y su pai acusado de corromper menores, y al día siguiente otro pai local fue acusado 
de asesinar ritualmente a una adolescente. En la primera nota sobre el allanamiento al templo de Umbanda, por ejemplo, se afirmaba: "En el barrio de Belgrano funcionaba un templo umbanda, donde se venían llevando a cabo sesiones de magia negra con la participación de gran cantidad de personas y sacrificios de animales con cuya sangre eran mojados los participantes. Entre ellos, la policía encontró chicas menores de edad, dos de las cuales, de 15 años, habían abandonado la casa de sus padres no hace mucho, seducidas por las promesas del líder de la esotérica secta [...] "Estamos viendo todos los días como se presentan denuncias por jovencitos y jovencitas que decidieron abandonar su hogar tras la oratoria un mundo mejor prometido por seudolíderes carismáticos y esotéricos [...]" explicaba a Clarín un funcionario policial. $Y$ agregó que las sectas han proliferado en forma alarmante en los últimos años" ("En un templo umbanda sacrificaban animales durante las ceremonias”, Clarín 27/7, nuestro énfasis).

La interpretación de los activistas anti-sectas, recogida y aceptada por los periodistas, de que las sectas "captan" principalmente a jóvenes se ve confirmada por el sacerdote que denunció la realización de un crimen ritual en Buenos Aires y por otros dos expertos en minoridad y adolescencia.

Las declaraciones del sacerdote fueron particularmente relevantes porque trajeron el problema de lleno al contexto local. "Lo de Brasil no es nuevo, y mucho menos en Argentina, donde ya hay antecedentes de sacrificios humanos en rituales de magia negra" ("Un cura acusa a un pai por el crimen de una chica" -Clarín 29/7).

En sus declaraciones, queda claro que éste no es un hecho aislado, sino vinculado a la temática de la sectas: "Es un aluvión el de las sectas, para el que no estabamos preparados [...] Los mediums y los pai la hacen facil [...] La miseria educativa facilita el terreno para que cualquier inspirado domine al que está debilitado”. (“En busca de la LUS”-Página 12 29/7).

Su interpretación es avalada por dos expertos en menores y jóvenes cuya opinión sobre el caso fue publicada en todos los diarios y pasada en los noticieros televisivos del día: "Atílio Alvarez, presidente del Consejo del Menor y la Familia, advirtió ayer que "las sectas que operan en el país se aprovechan de niños y adolescentes. Por lo tanto, hay que evitar la proliferación de estos grupos con conductas sicópatas”. En medio de la conmoción que produjo el descubrimiento de que en Brasil y la Argentina existen asesinatos rituales de chicos, Alvarez aseguro que "el solo hecho de captar como víctima a un niño 
constituye un delito, aun cuando no se lo mate o se lo induzca al suicidio" ("Estos grupos están enloqueciendo a la gente”-Clarín 29/7, nuestro énfasis). "Juan Yaria, director del Instituto de Drogadependencia de la Universidad del Salvador, alertó sobre el hecho de que "los barrios están llenos de sectas que toman a los drogadictos y a los chicos de la calle. Estos grupos tienen aceptación porque la gente perdió su concepto de solidaridad. La gente esta muy angustiada y se apega a sus lideres". [...] "Los chicos estan muy solos -advirtio- En todas las clases sociales. La mayoría de los que tienen transtornos de conducta son los que necesitan padres. Y cuando no tienen padres normales, buscan padres enfermos: el líder de un culto umbanda, un pai, un delincuente o el jefe de una banda de drogadictos". Analizó las propuestas de las sectas señalando que "en estos grupos siempre hay alusiones al fin del mundo, un culto al satanismo, se separan de todo y se crean delirios organizados. Estos grupos están enloqueciendo a la gente" ("Estos grupos están enloqueciendo a la gente” -Clarín 29/7, nuestro énfasis).

Estas declaraciones de autoridades en temas de drogas y de minoridad confirman la idea de los "especialistas en sectas" de que las sectas son peligrosas para la sociedad, que sus líderes son sicópatas que crean estructuras delirantes y ratifican la sensación de que los menores son las víctimas preferidas.

La preocupación de los medios por "las sectas" queda evidenciada cuando -luego de las acusaciones contra los pais locales- los diarios sacan informes especiales de dos y tres páginas, así como editoriales, sobre el tema. Los títulos de los mismos ya muestran cómo éstas son concebidas como "un problema” y cómo el marco interpretativo de los activistas anti-sectas se ha vuelto hegemónico: "En el pais hay 5000 sectas con mas de un millón de miembros. Las más peligrosas son las que hacen lavado de cerebro, dicen los especialistas" (Clarín 2/8, doble página). "Con el diablo en el cuerpoInforme especial: mitos, miedos y seducción de las sectas" (Título en primera página, diario Página 12 2/8, nota de dos páginas y medio).

Las notas posteriores, aparecidas a mediados de agosto, que informan sobre las actividades de la Secretaría de Cultos No Católicos (envío de una nueva ley de libertad religiosa al parlamento; reformas al Código Penal sobre delitos relacionados con el ámbito religioso) y acerca del informe sobre nuevos movimientos religiosos presentado ante la Conferencia Episcopal Argentina brindan una inequívoca impresión de que toda la sociedad argentina está preocupada por las actividades de las "sectas". 
Si los reclamos de los activistas anti-sectas (primary claims-making en términos de Best, 1991) son tomados y reflejados por los medios, no es menos cierto que éstos a su vez efectúan un proceso de elaboración de reclamos secundarios, es decir, adaptan los reclamos primarios según sus propias preocupaciones y convenciones (secondary claims-making, según el mismo autor). El propio mote de "secta satánica" con que se tipifica el caso no refleja la interpretación de los activistas anti-sectas; éstos en sus conferencias de prensa señalan que LUS es una secta destructiva pero no satánica, y que por su doctrina es más probable que se hayan encargado de proveer de niños para sacrificios -en busca de rédito económico- que los hayan sacrificado ellos mismos.

La utilización masiva en los medios de la denominación "secta satánica” probablemente se pueda explicar por tres razones vinculadas a las características del trabajo periodístico. En primer lugar, la necesidad de utilizar la información (y por ende la interpretación que la moldeaba) que llegaba desde Brasil. El marco interpretativo dominante en Brasil, que tipificó el hecho como un "ritual satánico" (como veremos con más detalle a continuación), también coloreaba las noticias argentinas, aunque de una manera subordinada a la interpretación hegemónica localmente -la de los activistas anti-sectas. En segundo lugar, el interés que puede suscitar la actividad de "sectas satánicas" en términos de drama y novedad, elementos indispensables para la construcción de la noticia. En tercer lugar, la utilización de la palabra "satánica” como una metáfora que relaciona a un grupo con actividades nefastas y no como un concepto que describe una realidad etnográfica. En otras ocasiones los medios argentinos ya habían utilizado -y volverían a hacerlo en el futuro- la palabra "satánico" para referirse a grupos religiosos que causaban muertes aunque no adoraran al demonio.

Los medios realizan reclamos secundarios no sólo al hablar de una "secta satánica”, sino también al dar como un hecho la existencia de "crímenes rituales” o de "sectas satánicas “ en Brasil y en Argentina, cuando sólo se tenían pruebas fehacientes de un asesinato ritual en Brasil (el de Evandro que originó la controversia), indicios de otros en aquel país y apenas la interpretación particular de un sacerdote acerca de un crimen perpetrado en Argentina. A la conexión insubstanciada de hechos aislados que realizaron los diarios brasileros, se le agregan otras denuncias similarmente vagas realizadas en Argentina. El editorial del prestigioso diario La Nación es una buena prueba de esto: "De acuerdo con las denuncias que se han ido acumulando, la utilización de 
niños como víctimas propiciatorias en actos rituales constituiría, en algunos estados brasileños, una práctica más difundida de lo que trasciende [...] Entretanto, obispos de la Iglesia Católica han alertado sobre la posibilidad de que se estén intensificando las actividades de sectas que practican sacrificios de seres vivos en Formosa, en Catamarca y en Mar del Plata. En la mayoría de los casos se trataría de la decapitación de animales, pero no se descarta que en algunos ritos se hayan utilizado víctimas humanas". ("Ceremonias satánicas” -La Nación 3/8/92, nuestro énfasis).

La redacción pretendidamente cautelosa del editorial no oculta que éste postula como cierta la realización de sacrificios rituales de niños en Brasil y Argentina -no se escribe un editorial acerca de un tema que se considera inexistente- cuando las evidencias al respecto eran más que escasas.

\section{En Brasil}

Comparada con la Argentina, el desarrollo de la controversia en Brasil (donde ocurrió el único crimen ritual) tuvo menos ramificaciones. Como mencionamos anteriormente, en Brasil el caso fue tematizado como "magia negra” o "ritual satánico” (título que la Folha de São Paulo mantuvo a lo largo de los días) y no como "secta satánica”. Esta diferencia, repetimos, es importante porque no lleva, como sucedió en la Argentina, a focalizar la atención en grupos (desviantes o criminales), sino en determinados actos. El encuadramiento de lo sucedido dentro de un marco interpretativo de "magia negra" permitió a los periodistas de la Folha de São Paulo establecer relaciones entre los hechos de Guaratuba y varios otros a lo largo y ancho del país: los homicidios de cinco niños en São Luis; la noticia de un empleado de cementerio que vendía restos de niños en São Paulo; el hallazgo de huesos humanos en Rio Claro (SP) que quizás hubieran sido utilizados para magia negra; una niña violada y asesinada en Goiânia y el hallazgo de un cráneo humano en Viamão sospechado de haber sido utilizado en rituales de magia negra.

Sin embargo, este marco de "ritual satánico" está poco desarrollado ya que, salvo la genérica relación de todos estos hechos con la "magia negra” o los rituales satánicos, no hay una tipificación de las categorías de personas que participarían de estos rituales satánicos o de magia negra, ni una teoría de cómo funcionarían los grupos. No hay un marco interpretativo coherente y explícito (como sí lo había para las “sectas” en Buenos Aires) que dijera qué 
tipo de grupos eran éstos, cómo funcionaban y qué peligros sociales concretos acarrean (además de los homicidios). ${ }^{13}$

Los elementos implícitos del marco que une a estos distintos eventos como parte del mismo fenómeno social parece ser la inversión de valores sociales básicos que estos actos evidencian:

- la utilización, en los supuestos rituales, de seres humanos (principalmente niños) como ofrendas o de sus restos como parte de la parafernália ritual

- la frase "Deus está morto” encontrada en la camioneta de Teruggi (una de las primeras informaciones sobre el grupo) y la idea de que el Dios cristiano en realidad seria una potencia malvada. "A frase "Deus está morto" encontrada em uma das apostilas da "bruxa" Valentina é uma forte evidência de que as pessoas envolvidas nos rituais satânicos no Paraná seguem os preceitos clássicos da magia negra. Segundo o livro do filósofo João Ribeiro Junior, "O que é magia”, um dos fundamentos básicos do satanismo é a ridicularização e profanação do culto em que os participantes acreditam ou sob o qual foram educados" ("Frase da apostila indica que ritual seguiu magia negra” -Folha de São Paulo, 15/7).

Algunas características de los rituales también fueron interpretadas como una clara señal de que se trataban de "rituales satánicos":

- la invocación a Exu (aquí inequívocamente identificado, al menos por los medios, como el diablo);

el hallazgo de un dibujo del diablo con un niño en la panza;

la supuesta relevancia del número 7 para el grupo de Marceneiro. Según una supuesta confesión de éste, el grupo se proponía matar 7 niños rubios de 7 años, con nombres de 7 letras y que fueran a 7 colegios diferentes.

La poca consistencia del marco interpretativo utilizado en Brasil puede ser explicado por la ausencia de reclamadores que hegemonizaran la

${ }^{13}$ En términos de Bromley (1994) no habría en Brasil -al contrario de lo ocurrido en Argentina- una "countersubversion ideology"; un marco interpretativo que describiera en detalle la naturaleza del peligro. Según este autor, las ideologías contra-subversivas detallan: 1) el origen histórico y la ubicación actual de la fuerza subversiva, 2) la naturaleza de la organización subversiva, 2) la fuente y la naturaleza de su poder, y 4) el impacto social de su poder y organización (Bromley, 1994, p. 51). Bromley desarrolla esta teoría al comparar los movimientos anti-satanista y anti-sectas norteamericanos (y la convergencia entre ambos). A diferencia de lo ocurrido en Brasil, la preocupación por rituales satánicos en Estados Unidos se expresa en marcos interpretativos desarrollados y coherentes que sustentan a un movimiento social preocupado por este fenómeno (para un análisis en profundidad del pánico moral desatado por el satanismo en los Estados Unidos en la década de los 90 ver los artículos compilados por Richardson, Best y Bromley (1991) y el excelente trabajo de Victor (1993).

Horizontes Antropológicos, Porto Alegre, ano 4, n. 8, p. 114-150, jun. 1998 
interpretación del fenómeno -como sucedió en Argentina. Aunque varios expertos de distintos orígenes opinaron sobre el tema, podemos afirmar que no hubo reclamadores porque no existió un grupo de personas que aparecieran reiteradamente en los medios y activamente intentaran imponer una definición del problema. La figura del “especialista en sectas”, que ganó su lugar público durante la controversia LUS en Argentina, estuvo ausente en Brasil.

Los numerosos expertos que opinaron sobre el tema en la Folha de São Paulo y en las revistas semanales no lo hicieron más de una o dos veces cada uno, y provenían de actividades muy diversas: sociólogos, antropólogos, profesores de historia, sicólogos, filósofos, escritores, ocultistas, pais de santo, sacerdotes e inclusive activistas anti-sectas argentinos. Aunque hubo un leve predominio de profesores universitarios, como éstos provenían de distintas disciplinas tampoco tenían un marco interpretativo común para proponer. En sus declaraciones, más que una interpretación común, lo que prevalece es un esfuerzo por deslindar el evento de Guaratuba de otros fenómenos sociales presentes en el país. Más que decir lo que el fenómeno era (un caso más del accionar de sectas con determinadas características, como en Argentina) sus declaraciones señalaban lo que éste no era: no eran genuinas prácticas afro-brasileras, tampoco "verdadero" esoterismo. Eran obras de locos, sádicos, personas enfermas.

El sociólogo Reginaldo Prandi, por ejemplo, afirmó que Marceneiro, al matar al niño: "inverteu as coisas, ao acreditar que o sacrifício seria mais poderoso quanto violento. Na verdade, acabou fundando uma nova religião, que é nociva à sociedade porque baseia-se em retirar a vida de pessoas". ("Ritual inverteu as coisas, diz sociólogo" -Folha 14/7/92).

Similarmente, el antropólogo Vagner Gonçalves da Silva señaló que: "[...] nenhum dos cultos afro-brasileiros registra o sacrifício humano nas oferendas aos deuses" (Istoé 15/7/92).

Para el cineasta José Mojica Marins (creador de Zé do Caixão): “ritual satânico é coisa de sádicos” (Folha 2/8/92).

Hasta el ocultista Paulo Coelho separó las aguas entre el "verdadero" esoterismo y los hechos ocurridos en Guaratuba: "Os crimes ocorridos no Paraná não têm nada a ver com a bruxaria. Tem a ver com a perversidade humana [...] Esta tal de Valentina não é uma bruxa, é um monstro" (Folha 26/7/92). 
Las declaraciones de la mayor parte de los expertos señalaban que éstos eran hechos aislados, que no formaban parte de un fenómeno social mayor presente en el país. No hubo estimaciones sobre cuántos grupos de magia negra había en el Brasil, ni acerca de qué tipos de personas los componían o de cómo funcionaban.

Ante la ausencia de un marco interpretativo que identificara claramente al "enemigo" y su modus operandi, el pánico moral desatado por las acusaciones de secuestros y desapariciones de niños se mantuvo principalmente a nivel local -en el estado de Paraná. La caza de "brujas” no se extendió, como en Argentina, a toda una serie de grupos desviantes (las "sectas") sino que se limitó, en gran medida, a los imputados, directa o indirectamente, en el caso: el brujo Marceneiro y sus asociados, la familia del alcalde de Guaratuba, y el "brujo" argentino y su mujer brasilera. Contra ellos se movilizó la atemorizada población: sus casas fueron atacadas, se realizaron manifestaciones locales para que fueran aprendidos o enjuiciados rápidamente.

\section{Turistas, brujos y religiones extranjeras: imágenes del Otro}

El desarrollo que tomó la controversia acerca de los “crímenes satánicos” o las "sectas satánicas”, no sólo es ilustrativo acerca de cómo se construyó la desviación religiosa en cada país (el otro religioso o mágico) sino también -debido a la nacionalidad mixta de los líderes del grupo LUS- de cómo las imágenes del otro (extranjero) intervienen en este proceso.

Un análisis de las noticias en ambos países muestra un énfasis algo diferente en la atribución de culpabilidad de los involucrados. Los diarios brasileños parecen enfatizar más el rol del "brujo argentino" mientras que los argentinos, por el contrario, realzan el papel de la brasileña Valentina de Andrade. ${ }^{14}$ Según las suposiciones de los policías brasileros, Marceneiro habría entregado a Leandro (el niño desaparecido) a Teruggi para que el grupo

\footnotetext{
14 Aunque los titulares de las notas argentinas frecuentemente hablan del líder satánico o esotérico, en el cuerpo de las notas se habla continuamente de las enseñanzas de Valentina o se brindan perfiles de su historia personal (como en la nota de dos páginas "Valentina de Andrade: de corista en un cabaret a líder de la secta satánica” (Clarín 27/7) o los recuadros "Valentina Andrade, famosa en la Argentina” (Clarín 17/7) o "La concepción apocalíptica de Valentina” (La Nación 17/7). La impresión inequívoca dada por la cobertura argentina -y refrendada por los “especialistas en sectas”- es que ella es la jefa espiritual del movimiento y él cumple un rol secundario (similar al que cumplió su anterior marido).
} 
argentino los ultimara en ceremonias de magia negra; según las presunciones de las agrupaciones anti-sectas argentinas, Teraggi sería sólo un intermediario que por dinero facilitaría niños para ser ultimados en Brasil por Marceneiro.

Vemos que en Brasil, luego de un crimen terrible perpetrado por brasileros, se empiezan a canalizar las culpas hacia un grupo de argentinos (liderados por una brasilera, pero este hecho es desenfatizado) que pasan a ser sospechados de estar conectados no sólo con el único crimen comprobado, sino con hasta 10 desapariciones de niños más. En Argentina, luego que un grupo argentino es culpado de participar en el secuestro y asesinato de niños, se empieza a acusar a individuos argentinos pero que practican una religión brasilera de corromper y matar niños en Buenos Aires. Más allá de los intereses puntuales que puedan haber tenido los individuos que realizaron las denuncias (los policías brasileros por desviar la presunta culpabilidad del intendente y su familia hacia dos extranjeros; el sacerdote argentino por denunciar a una "secta" competidora) cabe interrogarse acerca de la repercusión que estas denuncias tuvieron. Por qué en dos sociedades -aunque en la brasilera tan sólo a nivel local- se desata un pánico moral y por qué toma este rumbo de mutua expulsión y expurgación de la culpa?

La respuesta más inmediata parece ser que en ambas sociedades hubo una necesidad de realizar un "distanciamiento cognitivo" del macabro hecho, o sea, expulsar hacia afuera de la sociedad a los perpetradores del asesinato ritual de un niño. ${ }^{15}$ Para el caso brasilero, ya vimos algunas estrategias de distanciamiento: los antropólogos, sociólogos y pais de santo señalando que éstas no eran genuinas prácticas religiosas afro-brasileras; algunos ocultistas de renombre afirmando que las "verdaderas" brujas no usan sangre ni matan. Culpabilizar a un grupo de argentinos constituye una forma más radical de la misma estrategia, ya que en este caso los asesinos no sólo quedan fuera de la

${ }^{15}$ Chidester (1988) utiliza el concepto cognitive distancing para analizar la reacción de los diversos sectores de la sociedad norteamericana ante la matanza/suicidio colectivo de cientos de americanos seguidores de Jim Jones en Guyana en 1978. Según este autor, hubo tres formas de distanciamiento cognitivo que expurgaron este hecho fuera de la cultura y sociedad americana: 1) distanciamiento sicológico: al afirmarse que los devotos de Jim Jones estaban locos o habían sido víctimas de un lavado de cerebros, 2) distanciamiento político: todos los funcionarios que habían estado en contacto con Jones cuando éste era un exitoso pastor en San Francisco luego negaron que lo conocieron; o al argumentarse que los sucesos sólo se podían explicar como una anomalía acontecida en la selva guyanesa (similarmente, el premier de Guyana se distanció del hecho diciendo que era un problema americano) y 3) distanciamiento religioso: cuando los líderes de las iglesiasnegras y otros líderes evangélicos afirmaron que Jones no era un legítimo pastor, o, en una versión más extrema, que estaba poseído por el demonio (Chidester, 1988, p. 24-46).

Horizontes Antropológicos, Porto Alegre, ano 4, n. 8, p. 114-150, jun. 1998 
auténtica religión o del verdadero esoterismo, sino que no pertenecen a la sociedad nacional. Ante la (imposibilidad de poder explicar cómo el intendente de una ciudad, su mujer e hija pueden estar comprometidos en el asesinato de un niño, es necesario desplazar geográficamente el locus de culpabilidad.

Para el caso argentino, luego de tener que aceptar que era un grupo de individuos de esa nacionalidad quienes, en un remoto rincón de Brasil, se dedicaban a secuestrar y asesinar niños, hubo un progresivo distanciamiento cognitivo mediante el cual la culpa se desplazó hacia: individuos anormales que pertenecían a una secta, que para peor sería satánica, creada por una brasilera, y finalmente hacia individuos argentinos pero que estaban contaminados por una religión brasilera (los pais locales). De esta manera el crimen fue expulsado hacia formas progresivamente más ajenas a la cultura nacional.

Además de la necesidad de efectuar un distanciamiento cognitivo, hay otras razones que se pueden esgrimir para intentar comprender por qué una religión brasilera en suelo argentino, y turistas argentinos en suelo brasilero se convierten en promotores de un pánico moral. Diversos autores señalan que los pánicos morales suelen expresar tensiones sociales no resueltas, la frustración de determinados grupos o sectores de la población ante condiciones irritantes (Goode; Ben-Yehuda, 1994; Victor, 1993).

Proponemos, entonces, que para entender la dimensión y el rumbo que tomaron los hechos de Guaratuba en Brasil, es necesario tomar en cuenta algunas fuentes de tensión social. Como parte del contexto nacional la creciente preocupación en ese país por el maltrato y los asesinatos (no necesariamente rituales) de niños en todo el país. ${ }^{16}$ Como parte del contexto local, la masiva afluencia todos los veranos de turistas argentinos a los estados del sur, con las inevitables fricciones que estos desplazamientos causan. Resulta sugestivo que Teraggi y Valentina lideraban, precisamente, un grupo de argentinos que habían ido (al menos) dos veces a veranear a Guaratuba. La idea de que la presencia de grupos de extranjeros (ya sean turistas o inmigrantes) puedan ser

\footnotetext{
${ }^{16}$ A raíz de los sucesos de Guaratuba se reabrieron 10 casos de desapariciones de niños en el estado de Paraná ocurridas entre 1987 y 1992. Se imprimieron carteles con las fotos de ellos y con la leyenda: “Cuide do seu filho, ele pode ser o próximo. Ajude a encontrar nossos filhos”. Luego de que se mostrara el video de Teruggi en trance supuestamente pidiendo que se mate a un niño, la Sociedad de Búsqueda de Niños Desaparecidos, formada en Curitiba -según el diario Clarín a raíz de estos sucesos-realizó una marcha en esa ciudad en que se exigía el castigo del brujo argentino y de su mujer ("Forman la sociedad de Búsqueda de Niños Desaparecidos”-Clarín 31/7).
} 
un peligro para el bien más preciado de una sociedad (sus niños) no es nueva, y ha dado origen a innumerables leyendas urbanas y rumores. ${ }^{17}$

Para el caso argentino, el pánico moral desatado por el caso LUS, que abarcó también a las religiones afrobrasileñas y a los grupos religiosos no tradicionales en general (etiquetados como "sectas"), es clara evidencia del recelo con que algunos sectores de la sociedad ven la expansión de prácticas que consideran delirantes mágicas, o nocivas para la sociedad en general (Frigerio, 1993, 1995, 1996a, 1996b). La sucesión de acusaciones sin fundamento que se hicieron contra el grupo LUS, los pais locales y las extrapolaciones que a raíz de ello se realizaron sobre la peligrosidad de las sectas no podrían haberse llevado a cabo sin la presencia activa de reclamadores, pero tampoco sin un contexto social y cultural determinado que influyera para que estas acusaciones fueran inmediatamente aceptadas por vastos sectores de la sociedad y por todo el periodismo.

Finalmente, no podemos dejar de señalar un detalle que da cuenta de las conflictivas y a menudo confusas relaciones que se están dando entre argentinos y brasileros a raíz del acelerado proceso de integración regional que se está llevando a cabo. No deja de ser irónico que el momento de mayor agitación en la prensa de ambos países (registrado en la primera plana de los diarios Folha de São Paulo y Clarín de Buenos Aires) fue cuando la policía mostró el video de Teruggí en trance y éste, en portuñol, pronunció una frase que fue interpretada como "Matem a criancinha que eu pedi, é riqueza energética”. Un enviado especial del diario Clarín describe la importancia que se le adjudicó a esta frase: "El video acusador: El jueves 23 de julio a las 3 de la tarde, el jefe de la policía civil de Paraná tuvo la certeza de que había encontrado finalmente la punta del ovillo para relacionar a la secta LUS con la muerte de Evandro y la desaparición de Leandro (En un video secuestrado) los investigadores encontraron por primera vez, "algo más que un indicio". Todo dependía de que la traducción de una frase pronunciada por Teruggi, en la que mezcla el español y el portugués, fuese correcta. Para traducirla, el jefe de policía convocó en su despacho a los enviados especiales de Clarín.

17 Campion-Vicent (1990), por ejemplo, examina los rumores que circulan en varios países latinoamericanos acerca de que niños del área estarían siendo raptados y asesinados para que sus órganos fueran utilizados por norteamericanos. Leyendas y rumores más antiguos culpabilizan a judíos o gitanos por secuestros y muertes de niños. 
La frase textual del líder de la secta era: "Maten la criancinha que yo pedí. Es riqueza energética”. A las 4 y media de la tarde llamó a conferencia de prensa para mostrar el video...” (Clarín 26/7/92, nuestro énfasis).

Varios días más tarde, sin embargo, se estableció que la frase correcta era: "Mas tem criancinhas que são experientes" (Folha, 7/10) -como ya habían afirmado seguidores de Valentina en un programa de televisión argentino. ${ }^{18}$ El incidente es doblemente revelador. Por un lado, muestra la importante función que cumplen los periodistas como reclamadores secundarios -aunque no lo menciona explícitamente, el periodista de Clarín se adjudica un papel importante en la traducción (errónea) de la frase que convencería al público de la culpabilidad de Teruggi. Por otro, es una acabada muestra de los malentendidos que frecuentemente surgen en la interacción de individuos de ambas nacionalidades, debido a las barreras culturales e idiomáticas que aún persisten.

\section{Conclusiones}

El asesinato en el sur de Brasil de un niño en un supuesto contexto ritual inició un pánico moral a nivel local que se extendió a, y se amplificó en, la Argentina. Tanto en este país como en el estado de Paraná, en Brasil, se dieron procesos de etiquetamiento de la desviación social y de la construcción de un problema que se caracterizaron por una inusitada dinámica e intensidad. Un número importante de individuos se preocuparon por una amenaza -los brujos asesinos de niños en Brasil, las sectas satánicas en Argentina- que luego se supo era prácticamente inexistente. Junto con esta preocupación desmesurada, se crearon figuras demonizadas (folk devils): estereotipos desviantes que identificaban al enemigo y se reclamaron medidas especiales para su control.

La reacción social, en un caso nacional, y en otro local, por lo tanto, se ajusta a los parámetros propuestos por Goode y Ben-Yehuda (1994) para caracterizar a los pánicos morales.

18 Seis años después, la frase todavía es utilizada para estigmatizar a los umbandistas argentinos. En un talk-show de marzo de 1998 titulado “Sectas Diabólicas” -que en realidad versaba sobre la Umbandaun integrante del público señaló como acusación que hacía unos años se había mostrado por televisión un video en el cual un pai pedía que mataran a un niño. Nadie lo rebatió. 
En la Argentina, la existencia de reclamadores ayudó a crear una imagen más definida y completa de los folk devils (las “sectas”) y contribuyó a que la dimensión del pánico fuera mayor, como también sus consecuencias:

Tematizó a "las sectas" como un objeto de interés para los medios; elevando su nivel de noticiabilidad (newsworthiness).

Permitió que los activistas anti-sectas se convirtieran en los dueños del problema durante casi tres años. Su interpretación de las sectas (como grupos cuasicriminales que lavan cerebros y cuyo target son los adolescentes a quienes separan de su familia) se hizo hegemónica, así como las cifras que brindaban acerca de la cantidad de sectas presentes en el país.

Si bien la Umbanda fue uno de los principales grupos afectados por el pánico moral, se instauró una sospecha generalizada en el país contra los grupos religiosos no tradicionales. Cuando en diciembre de 1992 -unos meses después de los hechos aquí relevados- se realizó una encuesta sobre discriminación $(\mathrm{n}=1900)$ y se preguntó a los 1.900 individuos encuestados si “debía haber libertad religiosa para” ciertos grupos, el porcentaje que contestó que debía haberla para "las nuevas sectas" fue muy bajo (28\%). ${ }^{19}$

- Instaló la sensación de que algo había que hacer respecto de estos grupos: se aceleró la presentación al Senado de la nueva ley de cultos (formalmente algo más restrictiva que la anterior) y se elaboraron las reformas al código penal relativas a delitos en el ámbito religioso. Según los diarios de la época, éstas incluirían el crimen de "captación de conciencia”; sin embargo en la versión que tiempo después fue enviada para su sanción, esta figura no fue incluida.

- El pánico moral continuó en abril y septiembre del año siguiente (1993) cuando, nuevamente, todos los medios nacionales se ocuparían del tema de "las sectas" debido a las muertes de los Davidianos de David Koresh, en Waco, Texas (abril) y al allanamiento de comunidades del grupo La Familia (ex ${ }^{\mathrm{TM}}$ Niños de Dios) en Buenos Aires (septiembre).

En Brasil el pánico moral adquirió dimensiones menores, y se restringió casi exclusivamente al estado de Paraná -donde se realizaron manifestaciones

${ }^{19}$ Cuando se trataba de grupos religiosos tradicionales, el porcentaje de individuos que creían que "debían tener libertad religiosa” era mucho mayor. Las respuestas positivas llegaban al 88\% para los Judíos y Protestantes, y bajaban a medida que el grupo se aproximaba más al estereotipo de “secta”: Evangélicos (85\% ), Budistas (83 \%) y Testigos de Jehova (64\%). La encuesta fue realizada en diciembre de 1992 -aunque fue publicada meses más tarde (“Un mapa de los prejuicios” -Página 12 4/4/93). 
masivas como el apedreo de la casa del intendente o marchas reclamando castigo a los responsables. A nivel nacional, la inquietud por los "crímenes satánicos”, se evidenció principalmente en los reclamos secundarios de los periodistas que se esforzaron en establecer conexiones entre una serie de eventos a lo largo del país que estaban poco o nada relacionados pero que -dentro de su marco interpretativo- evidenciaban actividades de magia negra. Este marco, sin embargo, no instauraba una interpretación que identificara claramente a los desviantes ni describiera su modo de operar o las consecuencias sociales de su accionar; mucho menos las medidas a tomar para conjurar la amenaza -elementos que suelen caracterizar a los marcos propuestos por reclamadores especializados.

Sin duda, además de la existencia o no de reclamadores que propusieron ciertos marcos interpretativos para comprender los hechos reportados, también hay que tomar en cuenta los temas culturales propios de cada sociedad, que hacen que los marcos interpretativos propuestos por los reclamadores sean más facilmente aceptados por periodistas, políticos, funcionarios y el público en general. De esta manera, podemos entender mejor la rapidez con que fue aceptado en Argentina el marco interpretativo de la desviación religiosa propuesto por los activistas anti-sectas. Este resuena fuertemente con temas culturales propios de dicha sociedad: una desconfianza general hacia pautas culturales desviantes y una imagen ideal de la sociedad argentina como racional y moderna, donde las religiones mágicas y/o encantadas no tienen lugar, salvo como un síntoma de patología social (Frigerio, 1995). Por otro lado, la imagen ideal de la sociedad brasilera que sus miembros tienen suele ser la de una sociedad sincrética, con una fuerte presencia de lo sobrenatural en la vida cotidiana (DaMatta, 1984; Oro, 1992; Sanchis, 1994, 1997). Una auto-imagen de este tipo acepta más facilmente prácticas religiosas de diverso tipo (incluyendo mágicas y encantadas) y no se identifica fácilmente -como sucede en Argentina- con explicaciones patológicas y medicalizantes de la diversidad religiosa.

Los temas culturales informan también los propios marcos interpretativos de los periodistas -ya que éstos dependen en gran medida del contexto social y cultural en que actúan (Van Dijk, 1990). Así, en Brasil, donde las religiones afrobrasileras han ganado una cierta legitimidad luego de varios años de persecución y luego estigmatización (Concone, 1996), los periodistas ya no consideran a un asesinato ritual como un comportamiento probable o habitual 
dentro de los terreiros de candomblé o umbanda. ${ }^{20}$ En Argentina, por el contrario, donde los sacrificios de animales siempre han sido el principal estigma de estas religiones (Frigerio, 1991a, 1991b), la práctica de sacrificios humanos podría parecer probable para periodistas que poco o nada saben acerca de estas religiones. $^{21}$

Para concluir, qué es lo que indica este episodio nos indica, de una manera más general, acerca de la constracción de la desviación religiosa en Argentina y Brasil?

En Brasil parece haber una construcción a la vez más restringida y abstracta -pero también más drástica- de los desviantes. Es abstracta porque los desviantes no son identificados claramente; son los practicantes de magia negra, se definen por sus actos antisociales y principalmente, criminales -asesinatos de niños. Son definidos negativamente, por lo que no son: no practican verdadera religión afrobrasileña, tampoco verdadero esoterismo. Es restringida porque son pocos los individuos concretos que se pueden encontrar que encajen en este estereotipo -principalmente porque no hay una teoría que los identifíque o que explique su proceder. En Brasil, fuera de los crímenes,

${ }^{20}$ Dos ejemplos muestran cómo los periodistas brasileros - de manera diferente que sus colegas argentinosno responsabilizaron a las prácticas religiosas por los crímenes. El titular de la primera nota de la revista Istoé (15/7, nuestro énfasis) fue: “Crimes de Exu: Assassinos usam orixá de candomblé para tentar justificar a barbaridade de seus rituais”. De manera similar, en la primera nota sobre el caso aparecida en la revista Veja, el periodista señaló “É tolice tentar explicar esse tipo de crueldade animalesca por alguma deformação religiosa. Acontece que a vastíssima maioria dos evangélicos e umbandistas jamais cometeriam atrocidades desse tipo" (Veja, 15/7). A pesar de esta cautela, el periodismo brasilero (o al menos el diario Folha de São Paulo) realizó una autocrítica de su cobertura de los hechos. En dos oportunidades, el ombudsman de la Folha criticó el excesivo énfasis dado por el diario a la hipótesis del crimen ritual, la ligereza con que se llamó a los sospechosos de "brujos" - en base a la escasa evidencia que involucraba a varios de ellos- y la rapidez con que se transmitió la versión policial de los hechos ("A imprensa caça suas bruxas” y “Os adoradores do diabo, a P2 e a imprensa”-Folha 18/10/92 y 8/11/92). En Argentina, donde el pánico moral -que fue creado en buena medida por la propia forma en que los medios cubrieron los hechos- adquirió dimensiones mayores, no hubo ninguna autocrítica de los periodistas. La única rectificación realizada en este país fue la de uno de los entonces activistas anti-sectas, Alejandro Agostinelli, quien en una nota sobre "sectas” aparecida en la revista cultural La Maga dos años después, reconoció que las conclusiones a las que llegaron en el caso LUS fueron precipitadas y motivadas por la creencia en un marco interpretativo (el de los activistas anti-sectas) que declara ya no compartir ("El chasco de las acusaciones contra Valentina”, La Maga 4/5/94).

${ }^{21}$ Como un factor adicional a tener en cuenta en lo que atañe a los marcos interpretativos periodísticos, la denuncia sobre el supuesto asesinato ritual en Argentina fue realizada por un sacerdote católico, párroco en un barrio humilde, joven un día después que otro pai fuera arrestado por (supuesta) corrupción de menores. Los sacerdotes -especialmente los que trabajan con grupos populares- gozan, entre los periodistas argentinos, de una alta credibilidad que sin duda influyó en el crédito brindado a su acusación.

Horizontes Antropológicos, Porto Alegre, ano 4, n. 8, p. 114-150, jun. 1998 
muchos comportamientos religiosos minoritarios parecen estar permitidos sin despertar sospechas. Finalmente, es drástica porque, quienes son rotulados como desviantes no practican una forma suave de desviación, sino dura -crímenes o actividades antisociales.

En Argentina, por el contrario, parece producirse una construcción más detallada y justificada -sobre todo "científicamente”- de la desviación. Se brindan características que se supone identifican a las "sectas", a sus modos de operar, los problemas sicológicos que traerían aparejadas para sus miembros y las consecuencias sociales negativas que surgirían de su accionar. Esta construcción es también más abarcativa, ya que comprende a muchos individuos, grupos y comportamientos. Pocos comportamientos religiosos son considerados "normales"; los que no ocurren dentro de las iglesias históricas son considerados desviantes, con probables consecuencias perjudiciales para quienes los practican y para toda la sociedad. En el caso que aquí analizamos, el arco de sospechas parte del grupo LUS, se abre hacia la Umbanda, y luego hacia todas las "sectas" -o sea, todo el espectro religioso más allá de los católicos, judíos o protestantes históricos. Es menos drástica porque, aunque hay más comportamientos religiosos rotulados como desviantes, se considera que esta forma de desviación no necesariamente es dura (criminal). Sin embargo, se instaura un clima de sospecha en el cual cualquier comportamiento religioso extraño es potencialmente perjudicial.

\section{Referências}

ALSINA, R. La construcción de la noticia. Barcelona: Paidós, 1989.

BARKER, E. Religious movements: cult and anticult since Jonestown. Annual Review of Sociology, n. 12, p. 329-346, 1986.

BECKER, H. Outsiders: studies in the sociology of deviance. New York: Free Press, 1963.

BECKER, H. Whose side are we on? Social Problems, n. 14, p. 239-247, 1967.

BEST, J. Threatened children: rhetoric and concern about child-victims. Chicago: University of Chicago Press, 1990. 
BROMLEY, D. The social construction of subversion: a comparison of antireligious and anti-satanic cult narratives. In: SHUPE, A.; BROMLEY, D. (Ed.). Anti-cult movements in cross-cultural perspective. New York: Garland, 1994. p. 49-69.

BROMLEY, D.; SHUPE, A.; BUSCHING, B. Repression of religious “cults”. Research in Social Movements, Conflict and Change, n. 4, p. 25-45, 1981.

CAMPION-VINCENT, V. The baby-parts story: a Latin American legend. Western Folklore, v. 1, n. 49, p. 9-26, 1990.

CHIDESTER, D. Salvation and suicide: an interpretation of Jim Jones, the Peoples Temple and Jonestown. Bloomington: Indiana University Press, 1988.

COHEN, S. Folk devils and moral panics: the creation of the Mods and the Rockers. London: MacGibbon, 1972.

CONCONE, M. H. Imagem e identidade dos cultos afro-brasileiros (18801980). Teoria e Pesquisa, n. 16/17, p. 10-22, 1996.

CONRAD, P.; SCHNEIDER, D. Deviance and medicalization: from badness to sickness. Philadelphia: Temple University Press, 1992.

DAMATTA, R. O que faz o Brasil, Brasil?. Rio de Janeiro: Rocco, 1984.

FRIGERIO, A. Nuevos movimientos religiosos y medios de comunicación: la imagen de la Umbanda en Argentina. Sociedad y Religión, n. 8, p. 69-84, 1991a.

FRIGERIO, A. “La Umbanda no es una religión de ignorantes y mediocres”: la estigmatización de las religiones afro-brasileñas en Buenos Aires. Revista de Antropología, n. 10, p.22-33, 1991 b.

FRIGERIO, A. "La invasión de las sectas": el debate sobre nuevos movimientos religiosos en los medios de comunicación en Argentina. Sociedad y Religión, n. 10/11, p. 24-51, 1993. 
FRIGERIO, A. La medicalización de la desviación social: las sectas y la sociedad argentina. 1995. Ponencia presentada. XIX Encontro Anual da ANPOCS, Caxambu, MG, out. 1995.

FRIGERIO, A. Religion as a social problem: changing cult images in Argentina. 1996a. Ponencia presentada. 46th Annual Meeting, Society for the Study of Social Problems, New York, Aug. 1996.

FRIGERIO, A. La evolución de la controversia sobre la Umbanda en Argentina (1985-1995): de la acomodación a la problematización. 1996b. Ponencia presentada. XX Encontro Anual da ANPOCS, Caxambu, MG, out. 1996.

FRIGERIO, A. La construcción de problemas sociales: cultura, política y medios de comunicación. Comunicação e Política, ano 2, n. 4, p. 137$149,1997$.

FRIGERIO, A. La construcción de la desviación religiosa en géneros de ficción: las "sectas" en series televisivas argentinas. 1998. Ponencia presentada. XXI Reunião da Associação Brasileira de Antropologia, Vitória, Espirito Santo, abr. 1998.

GAMSON, W. Political discourse and collective action. International Social Movement Research, n. 1, p. 219-244, 1988a.

GAMSON, W. A constructionist approach to massmedia and public opinion. Symbolic Interaction, v. 2, n. 11, p. 161-174, 1988b.

GAMSON, W. Talking politics. Cambridge: Cambridge University Press, 1992.

GAMSON, W.; MODIGLIANI, A. Media discourse and public opinion on nuclear power: a constructionist approach. American Journal of Sociology, n. 95, p. 1-37, 1989.

GAMSON, W.; STUART, D. Media discourse as a symbolic contest: the bomb in political cartoons. Sociological Forum, v. 1, n. 7, p. 55-86, 1992. 
GAMSON, W. et al. Media images and the social construction of reality. Annual Review of Sociology, n. 18, p. 373-393, 1992.

GITLIN, T. The whole world is watching: mass media in the making and unmaking of the new left. Berkeley: University of California Press, 1980.

GOODE, E.; BEN-YEHUDA, N. Moral panics: the social construction of deviance. Cambridge: Blackwell, 1994.

GUSFIELD, J. Drinking-driving and the symbolic order: the culture of public problems. Chicago: University of Chicago Press, 1981.

HILGARTNER, S.; BOSK, C. The rise and fall of social problems: a public arenas model. American Journal of Sociology, n. 94, p. 53-78, 1988.

LEWIS, J. (Ed.). The gods have landed: new religions from other worlds. Albany: SUNY Press, 1995.

ORO, A. P. Religiões populares e modernidade no Brasil. In: ORO, A.; TEIXEIRA, S. (Org.). Brasil \& França: ensaios de antropologia social. Porto Alegre: Ed. da UFRGS, 1992. p. 95-102.

RICHARDSON, J.; BEST, J.; BROMLEY, D. (Ed.). The satanism scare. New York: Aldine, 1991.

SANCHIS, P. Pra não dizer que não falei de sincretismo. Comunicações do ISER, n. 45, p. 4-11, 1994.

SANCHIS, P. O campo religioso contemporâneo no Brasil. In: ORO, A.; STEIL, C. A. (Org.). Globalização e religião. Petrópolis: Vozes, 1997. p. 103116.

SCHNEIDER, J. Social problems theory: the constructionist view. Annual Review of Sociology, n. 11, p. 209-229, 1985.

TUCHMAN, G. Making news: a study in the construction of reality. New York: Free Press, 1978. 
VAN DIJK, T. La noticia como discurso: comprensión, estructura y producción de la información. Barcelona: Paidós, 1990.

VICTOR, J. Satanic panic: the creation of a contemporary legend. Chicago: Open Court, 1993.

WOLF, M. La investigación de la comunicación de masas: crítica y perspectivas. Barcelona: Paidós, 1991. 